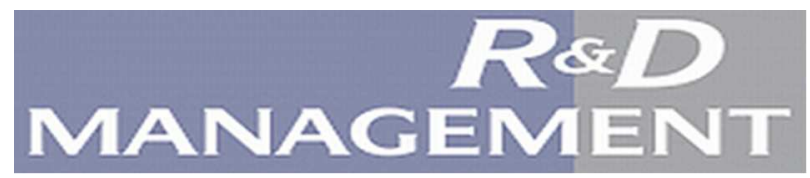

\title{
Patenting and the early stage high-technology investor: evidence from the field
}

\begin{tabular}{|r|l|}
\hline Journal: & R\&D Management \\
\hline Manuscript ID: & RP-2799.R3 \\
\hline Wiley - Manuscript type: & Research Paper \\
\hline Keywords: & $\begin{array}{l}\text { Patenting \& Investment, High-Technology Firms, Venture Capital } \\
\text { Investment, Qualitative \& Quantitative Evidence, Primary-Source Data }\end{array}$ \\
\hline Abstract: & $\begin{array}{l}\text { We discuss the importance of patenting to the venture capital investor in } \\
\text { high-technology firms. While literature suggests that patenting will have an } \\
\text { impact on the nature and level of investment, the investors themselves are } \\
\text { keen to suggest otherwise. We investigate this issue by the use of new } \\
\text { primary-source empirical data, gathered by fieldwork methods. Our results } \\
\text { help to explain a link between the existence of patenting and the level of } \\
\text { investment made. We further support our analysis with illuminating quotes } \\
\text { from investors currently active in the field. }\end{array}$ \\
\hline
\end{tabular}




\title{
Patenting and the early stage high-technology investor: evidence from the field
}

\begin{abstract}
We discuss the importance of patenting to the venture capital investor in high-technology firms. While literature suggests that patenting will have an impact on the nature and level of investment, the investors themselves are keen to suggest otherwise. We investigate this issue by the use of new primary-source empirical data, gathered by fieldwork methods. Our results help to explain a link between the existence of patenting and the level of investment made. We further support our analysis with illuminating quotes from investors currently active in the field.
\end{abstract}

\section{Introduction}

This paper reflects upon the methods used by UK-based venture capital investors to assess and evaluate potential investments in high-technology companies. The latter provide a particularly interesting opportunity for study, as they are often at the stage of product research and development, acknowledged to be an investment activity (cf. Hall et al, 2005), with innovation providing their competitive advantage (Hellman \& Puri, 2000). They therefore create idiosyncratic considerations for a potential investor (cf. Gompers \& Lerner, 2001). Early-stage companies such as these will, most often, fall into the 'small firm' category and, therefore, for financial reporting purposes will produce, at best, 'abbreviated accounts', which permit reduced financial disclosure, and, as such, are limited in their usefulness to external users (cf. Smith \& Cordina, 2014). The value of the company is embodied in the technology and the intellectual property of the individuals who work within the firm and is, therefore, of both 'hard' and 'soft' form (cf. Granstrand, 1998); or, as an accountant might put it, is represented by both 'tangible' and 'intangible' assets in the company's accounts. As intangible assets are often not fully explained in the accounts, the difficulty for the investor is to determine exactly what this figure in the accounts represents. Our motivation for this study is, therefore, to examine how venture capitalists evaluate potential investments in such firms. In particular, we hope to understand whether patenting, in itself, as a proxy for intangible assets, leads to higher investment.

If we consider 'knowledge' to form a part of the firm's 'intellectual capital', and 'technology' to develop naturally from this intellectual capital (cf. Granstrand, 1998), then we accept that the technology 
embodied in patents forms a part of the firm's value. As patents are measurable, in many different ways (in terms of scale, scope, timeframe, and so on), we can use this tangible measure to compare actual investment with patenting activity. Patents are often used as a proxy for invention and in recognition of its value (cf. Lanjouw et al, 1998). Therefore, we have an opportunity to determine whether investment behaviour is determined by technological activity.

Patenting has long been considered to be an important aspect in the evaluation of investment decisions. General Georges Doriot, who is considered by many to be the father of venture capital, set out strict criteria regarding the investments to be made by his venture capital firm, ARD, which was founded in 1946. Then, he argued that investment should only be made if "projects are protected though patents or specialised knowledge and techniques' (Ante, 2008, p. 112). If intellectual property is protected by patenting (cf. Sherry \& Teece, 2004; Granstrand, 1999), then this objective measure, which is readily available, can be used for a number of purposes, including the monitoring of competitors, the assessment of new technologies, the identification of possible new technological innovations (e.g. through mergers and/or acquisitions cf. Breitzman et al, 2002) and for human resource management (cf. Ernst, 2003). Odasso \& Ughetto (2001) also discuss the use of patent-based securitisations as a financial tool that might be leveraged on intellectual property assets (cf. Holgersson, 2013). Importantly, from our perspective, they can also be used by a potential investor as the starting-point for evaluating a new investment proposition (cf. Hirschey et al, 2001).

The importance of venture capital to high-technology start-ups has been well documented (cf. Bottazzi et al, 2008), and it has been credited with enabling the stratospheric growth of many high profile technology-based firms, such as ASOS, JustEat, King.com, Mimecast, Moshi, Net-a-Porter, Playfish and Skype and, further afield, Microsoft, Compaq, Oracle, and Sun Microsystems (cf. Jeng \& Wells, 2000). Of all the G20 countries, in 2010 the UK had the highest amount of GDP (=8\%) accounted for by the internet economy. This is forecast to grow to $12.4 \%$ and to contribute $£ 225 \mathrm{bn}$ to the overall UK economy by 2016 (Klein, 2013). So the relevance of the high-tech sector and its importance to the economy, through innovation, is undoubted (cf. Lerner, 2002). 
With such success stories in mind, a number of academics have argued that equity investors are likely to make use of signals that give an indication of the company's future (Armstrong et al, 2006; Baum \& Silverman, 2004) especially since, according to a report published by the British Business Angels Association, more than half of the companies in which business angels invest do not yet have any revenues (cf. Wiltbank, 2009). One possible signal of a future profitable opportunity can be patent ownership (Conti et al, 2011; Haeussler et al, 2012; Hsu \& Ziedonis, 2007; Lemley, 2000; Long, 2002; Nadeau, 2010), when viewed as an indicator of the intellectual property in an organisation (cf. Benassi \& Di Minin, 2008). This 'signal' argument has been further substantiated by Hand (2005), who shows a relationship between increases in revenues and increases in the number of patents in the healthcare and IT industries.

Investment in high-technology sectors is likely to be affected by capital market imperfections, partly because projects involving extensive research and development might prove to be financially unsuccessful (cf. Carpenter \& Petersen, 2002), although those which are successful might be extremely so. However, the uncertainty remains because of the information asymmetries between the investor and innovative firms and the difficulties in evaluating the outcomes of new ideas (cf. Seppä \& Laamanen, 2001). Further, the observed skewness of patent citations and valuations is an additional problem to overcome (cf. Granstrand, 2003; Griliches, 1998; Hall et al, 2005; Harhoff et al, 2003; Lanjouw et al, 1998; Narin, 1994; Scherer, 1999). Therefore, it is possible that an investor might choose a company with a strong management team, in favour of one with greater intellectual property, simply because it is easier to assess (cf. Hayton, 2005; Stevens, 1972; Knockaert et al, 2010). Set against these difficulties and in order to encourage innovation and patenting, the UK Government has recently introduced a so-called 'Patent Box', as a tax break on profits directly attributable to patents. Amongst its stated aims, this will 'provide an additional incentive for companies to retain and commercialise existing patents and to develop new innovative patented products. This should encourage companies to locate the high-value jobs associated with the development, manufacture

${ }^{1}$ Effective from 1 April 2013 
and exploitation of patents in the UK and maintain the UK's position as a world leader in patented technologies.' (HM Treasury, 2013).

The ability to patent is sometimes also seen by the venture capitalist to be a potential indicator of future survival. This is particularly evident in the technology sector (cf. Knockaert et al, 2010), where the chances of survival are much less if one does not own new innovative products (e.g. Baum \& Silverman, 2004). Increasingly, as Ernst \& Witt (2005) point out, firms are seeking to acquire innovations externally, and in order to do so, some objective measure of value must be obtained. The existence of a patent might further indicate that less effort is required by the venture capitalist; patenting is a long and costly process, and the fact that the firm's intellectual property is already protected means that they have already spent much time and effort on this process that the investor need not now repeat (cf. Haeussler et al, 2012). Despite the criticisms associated with patenting, investors are often unwilling to invest in the biotech sector, for example, unless there is intellectual property (IP) protection (Jackson, 2003). One of the reasons for this is that patents provide, cheaply, to outsiders significant information, which is not available from alternative sources (Long, 2002).

Given the number of start-up failures and the adverse selection associated with early stage investments, the legal protection afforded by patents can further be considered to be a signal of quality to potential investors (Nadeau, 2010). However, the issue of how to value a patent remains relatively unexplored. Following the Patents Act (1977), it became law that firms record details of those who have originated inventions, and the costs and benefits associated with those inventions, in order to evaluate a suitable compensation package for the employee (cf. Littler \& Pearson, 1979). However, it is not obvious that a potential investor would be party to such information.

This paper incorporates the ideas introduced above and provides new insight into patenting and venture capital investment (cf. Stevens, 1972). For example, we consider whether patenting is a sign for the venture capitalist to invest, whether that be in monetary amounts of in terms of a percentage stake in the business. Further, we examine whether or not there is an identifiable link between investment in companies 
with patents and venture capital funding. We do this by use of primary source date gathered 'in the field', and by statistical analysis, supported by comments from our respondents themselves. We proceed now below with an examination of the literature relevant to our field of study.

\section{On patents and investment}

\subsection{Patenting as a signal prior to investment}

Prior to investment in an unlisted and often unincorporated venture, the venture capitalist has very little to rely on, in terms of external validation of the company's performance (cf. Seppä \& Laamanen, 2001). For example, there will be no requirement for detailed financial accounts, nor for any report to shareholders. The existence of a patent, therefore, or activity surrounding pursuance of such a goal, can be seen to be an indicator or potential value, that is worthy of protection, and which may have associated future licensing revenue attached.

A number of previous studies have attempted to verify whether the number of patents is a measure which attracts financing (e.g. Odasso and Ughetto, 2011). Most of these studies, with the exception of some carried out amongst European firms, are based on North American data (e.g. Seppä and Laamanen, 2002). However, in a study carried out on German and UK biotechnological companies, Haeussler et al (2012) found that firms which have one patent application are able to obtain venture capital funding significantly faster than companies which do not have any patent applications. In other words, it would appear that investors see some value in the fact that a company has already gone through the due process involved in obtaining a patent. ${ }^{2}$ Furthermore, the chance of obtaining funding if a firm holds patent applications is found to be considerably higher. Another study carried out amongst German firms by Engel \& Keilbach (2007) reveals that, at the point of investment, firms which obtain venture capital backing are more likely to have a patent application in process than those which do not achieve backing.

${ }^{2}$ Though see also Breitzman et al (2002) for a discussion of the value of patents in the context of a merger. 
An important distinction must be made between patents applied for, and patents granted. Haeussler et al (2012) and Cockburn \& MacGarvie (2009) do not report an increase in venture capital financing for companies with patents granted, as opposed to patent applications. This might be due to the fact that the investor will have reviewed thoroughly the patent application prior to investing in the firm (Haeussler et al, 2012), and also that their focus might be more on the future of the firm (Cockburn \& MacGarvie, 2009). These studies contrast with Baum \& Silverman's (2004) study on biotech start-ups which shows evidence of an increase in venture capital funding, as a result both of the number of patents granted and of the number of patents applied for.

Whilst acknowledging that patents may increase the likelihood of obtaining funding, Mann \& Sager (2007) find no evidence to support this finding for the case of the software industry. They show that patenting prior to financing is related to performance, and argue that only a small portion of the firms under study had patents prior to financing. One must not assume however that these studies are entirely contradictory to the study by Hsu \& Ziedonis (2007), on patents as quality signals. Whilst Mann \& Sager's (2007) study is based on the software industry in the United States, that of Hsu \& Ziedonis (2007) is based on the semiconductor industry in the United States. This difference between industries is further confirmed, by Graham, et al (2010) which outlines that software start-ups are likely to hold no patents; but, on the other hand, start-up biotech and hardware companies will hold more patents. Furthermore, a study by Munari \& Toschi (2014), based on venture capital in the nanotech industry, sheds more light on the possible reasons for the differences between the studies outlined above. The authors confirm that a simple patent count does not make a difference to initial financing; but the number of patents classified by the patent office as being related to the nanotech industry does affect the investment decision of the venture capitalist.

Several authors have argued that not only does patenting increase the chances of obtaining venture capital financing at all, but that there is also a positive relationship between the number of patents and the actual monetary amount invested (Baum \& Silverman, 2004; Conti et al, 2011; Mann \& Sager, 2007; Schertler, 2007). Although Mann \& Sager (2007) question the relevance of patents for the purposes of the 
initial investment by the venture capitalist, they do identify a significant increase in the size of the investment made, according to the number of patents held. In this instance, note that Mann \& Sager's (2007) study is restricted to the software industry in the United States, and that the authors themselves claim that the results have low explanatory power. Although, for comparative purposes, throughout the study, they consider also the biotechnological sector, no reference is made to this sector with respect to the total amount of venture capital financing.

Baum \& Silverman (2004) argue that not only do firms receive more funding if they have more patents, but also if they are not granted any patents for a significant amount of time, they are likely to receive less funding than those who have more recently obtained patents (Baum \& Silverman, 2004). Whilst Mann \& Sager (2007) and Baum \& Silverman (2004) consider the number of patents granted, Schertler (2007), using a European dataset and Conti et al (2011), using a US based dataset of technological companies, study the link between venture capital financing and patent applications. Despite this difference, similar results are obtained across all four studies. Conti et al (2011) note, however, that this relationship is only statistically significant in the case of formal venture capital investment, and not in the informal venture capital market (business angels). However, not all studies show a clear relationsip between patenting and the amount of venture capital financing obtained. Munari \& Toschi (2014), for example, use a global dataset and find no evidence of any significant relationship between the amount of funding and simple patent application counts. Similarly no significant relationship is found between patent $\operatorname{scope}^{3}$ and the amount of venture capital financing.

The analyses by Kortum \& Lerner (2000) and Ueda \& Hirukawa (2008) seem also to be valid in countries where venture capital financing is not as developed as in the US and the UK. For example, Bertoni et al (2010) find that, in Italy, there is an increase in the number of patents granted and in the chances of obtaining funding. Note that this study shows that the relationship between venture capital and the number of

\footnotetext{
${ }^{3}$ The definition of patent scope is not definitive. It relates to the application made by the inventor, in which s/he must outline: "a specification containing a description of the invention, a claim or claims and any drawing referred to in the description or any claim" [Patents Act (1977, s.14(2)) (as amended), Intellectual Property Office (2011)]. See Merges \& Nelson (1990) for an interesting debate on this complex issue.
} 
patents is not simply attributable to an increase in financing, because it also takes into account the cash flow and debt financing of the firms under consideration. A similar relationship is identified amongst Japanese firms by Lynskey (2004) who argues that venture capital in Japan appears to be contributing to innovation, given that there is a link between both the number of new products and the number of patents applied for by firms in which venture capital is invested (cf. Sakata et al, 2009).

Whilst most of the studies outlined above consider the number of patents applied for or granted, Dushnitsky \& Lenox (2005) consider the number of patent citations ${ }^{4}$, which the authors use as a measure of innovation. They identify a positive relationship between the amount of venture capital invested and the number of future patent citations, although this relationship is not identified in industries where there is a strong intellectual property regime (i.e. where there are fewer disputes related to the intellectual property, e.g. chemicals, pharmaceuticals).

Graham et al (2010) analysed a number of different technological industries in the United States and found a two-way relationship between the holding of patents and the provision of venture capital: the venture capitalist is unwilling to provide funding if the firm has no patent; and the investee company is seen to engage in patenting activity in order to obtain funding. Whereas some studies have highlighted the positive emphasis venture capitalists give to patents, when it comes choosing which company to invest in (cf. Graham et al, 2010), others argue that there is a significant number of venture capitalists who claim a negative relationship between patenting and their investment decisions (Knockaert et al, 2010). Interviews carried out among entrepreneurs provide mixed views as to the importance given to obtaining patents in securing financing, possibly implying that, without patents, firms still can obtain financing on the basis of other selection criteria (Graham et al, 2010). Furthermore, entrepreneurs tend to think that patenting is not only seen as important by the venture capital investor, but also by other types of investors, namely commercial banks, family and friends (cf. Benassi and Di Minin, 2008).

${ }^{4}$ These being citations of a company's patents elsewhere e.g. by other patent applications (cf. Hall et al, 2000). 


\subsection{Post investment performance}

Engel and Keilback (2007) find that the firms in their sample that have attracted venture capital funding prove to be more successful in the longer term. Similar findings relating to the performance of venturecapital backed companies are identified by Hsu \& Ziedonis (2007) who indicate that companies which have a larger number of patents also appear to have a greater rate of successful exit by means of an Initial Public Offering (IPO) (Hsu \& Ziedonis, 2007). The relationship identified by Engel \& Keilbach (2007) is also confirmed by Schertler (2007) who identifies a significantly positive relationship between the number of early stage venture capital investments and patenting amongst the members of the EVCA i.e. across European countries.

Per contra, there is also a strand of the literature which indicates that patenting increases after venture capital funding is provided. The main study in this area is Kortum \& Lerner's (2000) industry wide study. The authors make use of a dataset which incorporates data from companies in twenty industries, for the time period 1965-1992. The study finds a strong relationship between patenting and the provision of venture capital. The authors cite two possible reasons for which venture capital backed companies may be patenting more. One of their arguments is that either the entrepreneur might be afraid that the venture capitalists would make use of his ideas themselves, or else they could be using this as a signal to attract more funding, as outlined above. A further possibility is given by Holgersson (2013), who suggests that investors welcome patents as a means of attenuating agency problems, through the improved control they provide of the firm's intellectual property. Ueda \& Hirukawa (2008) extend the study carried out by Kortum \& Lerner (2000) up to 2001, and confirm that, even during the later period, venture capital investment appears to be contributing to an increase in patenting activity as measured by patent counts; but they also argue that is was not necessarily synonymous with an improvement in the productivity of US manufacturing firms.

Since the studies above do not involve interviews with actual investors, they provide no supporting evidence for the underlying reasons as to why patenting increases after the first venture capital financing round. In fact, the majority of the studies discussed here are time series studies, based on data extracted from 
proprietary US venture capital databases. However, the authors of the various articles cited above attempt to provide suggestions for the increase in patenting following venture capital investment. Ueda \& Hirukawa (2008) argue, for example, that venture capital augments the competiveness of the firms in which funding is invested, which in turn leads to an increase in patenting. The authors extend their analysis to verify whether the reason for holding the patent is simply to block other firms from making use of the inventions without commercialising them (and hence leading to an increase in future profitability). Ueda \& Hirukawa (2008) find no evidence attributing the increase in number of patents to the blocking motive. Furthermore, they believe that given the nature of start-up firms, venture capital backed investors are more likely to patent than established firms. Patents also appear to be crucial in securing further financing (Ueda \& Hirukawa, 2008). Another possible reason outlined by Bertoni, et al (2010) is that given that more financial resources are available in venture capital backed firms, these organisations tend to invest more in research and development, leading to more patent applications.

Once again, contradictory results are obtained from different studies. For example, although at first sight, Engel \& Keilbach's (2007) work appears to indicate that venture capital increases the number of patent applications, a high variance in the number of patent applications leads to the results being not statistically significant, implying that there is only weak evidence, if any, that venture capital leads to an increase in patenting. Although these works provide opposing views, we must take into consideration that this could be due to the different methodologies, different countries and different industries considered by the studies.

\section{Research approach and data}

Our own research began with a series of unstructured interviews (cf. Burgess, 1984) with members of those associations directly involved with early-stage investments in high-technology firms, the aim being to get feedback from 'key communicators', or 'gatekeepers', at an early stage in the project, to endorse the work and to facilitate the further development of a future research agenda (cf. Morgan and Smircich, 1980). Seven unstructured interviews were undertaken in late 2011 (cf. Qu and Fumay, 2011) with representatives from 
early stage investor associations, representing investors in the United Kingdom and Europe. On average these meetings lasted for about an hour and included interviews with, for example, the chairman of a business angel support organisation, the chairman of the British Business Angels Association, and the Head of Research at the British Venture Capital Association.

The unstructured interviews had a broad-based agenda, which included discussion of: the general state of the UK and European venture capital and early stage investment market; the extent of the investment in high tech firms in the UK; patenting and early stage investments; patenting as a signal for possible investments; other intangible assets considered; research and development; the relevance of various patent measures prior to investment (number of patents, citations, patent family size); patenting and the size of the investment; patents following initial investment; and assistance sought by or offered to investors, with regards to analysing intangible assets. Whilst these initial conversations were not intended to provide data 'saturation' (cf. Guest, Bunce \& Johnson, 2006), they did enable us to generate ideas for a more structured research agenda.

Our semi-structured questionnaire was crafted in direct response to the feedback we obtained from our earlier unstructured meetings with the key communicators in the field. Excerpts relevant to this current paper are obtained in the Appendix. These questions were used during our meetings with venture capital investors and the responses they gave were noted on the hard copy, and digitally recorded, then later transcribed; and they are used in our quantitative (statistical) and qualitative (quotes) analysis below. Essentially, we have codified some of the questions, in order to allow for some statistical testing, while at the same time still allowing space for some more qualitative responses. Background data on investment levels and preferences were obtained from a standard introductory section, while detail on investor preferences and behaviour in relation to patents, for example, was gathered through the questionnaire section on intangible assets. Responses were coded as $(0,1)$ binary variables, in response to 'yes/no'-type questions, and Categorical or Likert variables (e.g. on a scale of 1 to 5) where preferences were expressed. 
The target participants were key personnel from members of the British Venture Capital Association investing in technological firms, including telecommunications, computer technology, biotechnology and the medical sector. Hence, venture capitalists which invest solely in basic materials, financials and/or in consumer goods and services do not fall under the scope of the study. Although the BVCA has more than 230 full members, only 45 of these were considered to be as suitable participants (investing in technology). Of these 45 organisations, some claimed that they did not actually invest in firms with intangibles, and others could not be contacted for interview. During the period August to November 2012, a total of 21 meetings were undertaken throughout the UK, with venture capital investors active in technology fields. The meetings took, on average just under one hour each, and Table 1 contains the names of the organisations from which our respondents were drawn.

\section{[Table 1 near here]}

The importance of venture capital in the economy lies in its role of providing finance to firms which have high growth opportunities, but which are not large enough to use internal financing or public equity (Mason, 1999; Mason \& Harrison, 2004). Usually investment is made at a very early stage, where financial information may not be of relevance to the investor. Beginning with this in mind, Table 2 now provides some basic descriptive statistics for our sample. By stage of investment, the modal response to our question, which asked respondents to identify up to five of the most common stages of investment for their organisation was at the early stage of firm development (76\%), seed (71\%) or startup (71\%). Clearly, these are not mutually exclusive. One investor explained the nature of his firm's investments:

'We invest in prototype, pre-revenue, pre-launch. It doesn't mean that we fund Powerpoint presentations or ideas. We fund good teams with big markets, good visions. The companies are normally six months to a year old, [so] there's normally very little to go on. All we ask to see is a bank statement, and if there are management accounts, then that's it. They wouldn't have published accounts'.

Roughly two-thirds of our investors would consider backing firms that were expanding or looking for growth. This latter finding is supported by comments from a representative of the British Venture Capital Association (BVCA), who said that 'venture capitalists are moving a bit away from seed and start-up and 
moving towards later stage ventures', while the representative from the British Business Angels Association (BBAA) concurred that 'the $\mathrm{VC}$ tends to be more comfortable with investing when there's a little bit more tangible growth in what the company is trying to achieve'. The remaining stages of investment were of little importance to these investors. So MBOs and MBIs, typically later-stage deals, were insignificant; not surprising, given the technology-focused investors with which we are concerned here.

\section{[Table 2 near here]}

The most important sector in which these investors chose to invest was the medical sector (81\%), followed by internet companies (76\%), mobile telecommunications (62\%), software (62\%), medical equipment (57\%) and healthcare (57\%). Again, these are not mutually exclusive responses, as investors were asked to 'tick all that apply'. While Cockburn and MacGarvie (2009) observe that the number of patents in the software industry has been increasing in recent years in the United States, they conclude that, given the increasingly complex patent situation in the software market, venture capitalists are becoming more reluctant to invest in software start-ups in the USA. However, we observe and confirm here that this is not the case in the UK, where the software industry retains the highest proportion of venture capital investment (BVCA, 2011). One respondent explained that 'fifty per cent of all investment is in the IT sector'; another said that 'VCs still like high tech ... it still has a lot of advantages, particularly in terms of low start-up costs, but it's very difficult'; and a further comment was that 'with regards to investment in high-tech firms, venture capitalists in Europe ... are moving away from capital intensive investment towards easy investment and capital efficient investment; software, social networking etc, and away from deep technology built on fundamental research'. The least targeted sector amongst our investors was pharmaceuticals, with just under a quarter (24\%) choosing to invest in this area. However, as we shall see, these investments were among the most significant when it came to patenting activity. One investor explained the difficulties in valuing intangibles as follows:

'We're taking a perspective of what the market might pay to buy this company in four to five years, mad as that sounds. And the market will value the intangibles because at that stage they would be expressed in performance. The market for intangibles is illiquid and fuzzy. Different parties who want to buy a company can come up with very different views of what intangibles are; if you take the 
accounting definition, any value placed above the replacement value of the assets. The question you have to ask is why would [investors offer] significantly different prices for a company? It's probably because they have come to a different set of beliefs of how can they could manage that business, in that market, given the set of intangibles that they have; and some buyers will believe that value is unique to them and affordable to them. The question is, how much of that value they give to the sellers or they wish to maintain for themselves. The one exception where you could value intangibles is in the pharmaceuticals or medical device area.'

The Secretary General of the Belgium Venture Capital Association explained that, 'from an investment point of view, the situation is quite good. High-tech sectors are very popular, despite an increase in investment in internet companies. In terms of Belgium, despite it being a small country, in terms of venture capital the situation is also very positive, and similar to the global outlook. There are good people, and good investment opportunities, for example, in the pharmaceutical sectors'.

Geographically, none of our investors chose the local area as a preferred region for investment, and only 10 per cent would target investments in their own region. Almost half (48\%) would consider investments throughout Europe, just under one third (29\%) invested on a national level, and 14 per cent would seek an investment anywhere in the world. One investor explained their market choice as follows: 'If I can see the size of the market is potentially very large - not just in the UK, but internationally, I can put another valuation of another [additional] million'. This shows that investors are willing to chase the right investment, wherever it might be, and that distance is not the barrier it once was. It also suggests that investors are willing to accept a 'hands-off', or remote, deal, rather than the more cautious 'hands-on' closerto-home investments of earlier years. As one investor explained further, 'all companies export to the US and Asia. Less than two per cent of our portfolio are in [this country]. Companies are registered here, headquartered here and founded here'.

By size of investment, we asked for the highest, lowest and average figures, in sterling. The mean figures, respectively, were $£ 5.1 \mathrm{~m}$ (highest), £2.13m (lowest) and $£ 2.03 \mathrm{~m}$ (average), with the highest investment considered overall being $£ 20 \mathrm{~m}$, and the lowest just $£ 10,000$. One said, for example, 'we invest in growth companies. The company would require capital to grow. We invest half a million to five million pounds'. We also then asked for the required equity stake that investors wished to take from an investment. 
The mean responses were 33\% (highest), 15\% (lowest) and 27\% (average). The highest equity stake, overall, was $80 \%$, and the lowest considered $5 \%$. So, on average, with a notable exception or two, we have a picture where investors would seek to have around a one-third, at most, but not necessarily a controlling, equity stake in the business. At the lower end, they are occasionally willing to consider quite small investments, while at the top end, they will invest millions in backing what they see to be a worthy business. One investor explained that 'any large VC firm typically wants to get between $25 \%$ and $35 \%$ over the life of the deal, and there's a whole mathematical model for a base. There are cases where you have more and cases where you have less'. Another added that 'we tend to put in money in small bits - that is, a number of investments over a period of time. Less than ten per cent is not enough to justify the need of an equity investor [but] we don't want to go above fifty per cent.' However, the chairman of a Scottish Business Angel support group (LINC Scotland) clarified that 'in early stage companies, ... it's all business angels ... because the banks are not willing to lend and the venture capitalist does not want to come in at the low end, so angels have to continue to finance companies'.

\section{Practitioners' views on patents and investment}

An investor might see signals of profitable opportunities through proprietary rights embodied in the form of patents (Armstrong et al, 2006; Baum \& Silverman, 2004). We therefore turn now to our respondents' views on patenting and related activities with, first of all, some 'yes/no' questions on whether patenting can act as such a signal to the investor [cf. Appendix, Q.2]. The mean responses to these questions are given in Table 3. Most investors $(83 \%)$ were willing to accept that a patent is a sign of innovative potential in the investee firm: e.g. 'it's a sign of some level of innovation, but we have found that innovation is the starting step of value creation within an enterprise and, more often than not, the value comes with the execution of the business plan, in leveraging that innovation'; and 'it is a sign of innovation, a business that's worth looking at because they've got some patents, but it's not necessarily valuable, because you can patent to many things'. Less than one third (28\%) thought that it showed evidence of entrepreneurial ability and experience, so the 
majority thought that it did not: 'I don't see a correlation between the number of patents and entrepreneurial ability - lots of academics have a number of patents, for example, and are not entrepreneurial at all'.

About one fifth (21\%) considered patents to be a sign of a profitable investment opportunity ('patents can be worth money - they are an asset'), but most did not. For example, one explained that 'it doesn't necessarily mean that a patent equals profitability; revenue and customers have to be taken into consideration'. Another added that 'people can patent all sorts of things; it doesn't say anything about whether the IP is executable and can create value for venture investment. There are lots of patents which don't give rise to any value whatsoever'. A further respondent explained: 'I have been involved with some investments where the Board has taken an active decision not to seek a patent, because it felt it could open up itself to greater competition by putting it up out there than not patenting.' Only 2 respondents thought that a patent might be a signal that less effort would be required by the investor saying, for example, 'it is a help, yes, as long as it still has plenty of life'; and 'if it's a good one, and timely, and highly commercially valuable then yes; otherwise it could be a mad scientist. We don't know until we look at the context'.

\section{[Table 3 near here]}

Whilst there is some agreement on patenting as a potential signal to the venture capitalist, the issue remains as to whether there is a link between patenting and investment. There are studies which show a positive relationship between the number of patents applied for and the amount of funding received (Haeussler et al, 2012; Hsu \& Ziedonis, 2007). Of great interest to us here, therefore, is the concept that investment, either in monetary or percentage terms, might be connected in some way to patenting activity [cf. Appendix Q.3-6]. Just under a quarter of our respondents thought that there was a link between the amount invested and whether or not the company has either applied for or owns patents ( $24 \%$, in each case). Of those who perceived this link to exist, comments like 'we often expect a higher valuation for companies with patents, given the time and resources required to generate those patents', 'a patent increases the value of the firm; there is also defensibility of the product, that would make it valuable', and 'if we believe it has commerciality, and a route to market' were common. 
A further respondent explained the importance of broader patent protection, as follows:

'We seek to understand. Are there multiple patents protecting that position, either through formulation, method of use, process patents combined with product patents, combined with delivery? Is there a family of patents? Because otherwise it's not credible. It's really hard to get a claim [that is] broad enough to be valuable in the market to prevent other people entering'.

On the other hand, where the investor foresees a potential problem with a patent, the lesser will be his investment in a company (cf. Mulder \& Vergragt, 1991): e.g. patent litigation issues 'worry us, and could put us off'. Related to this, one investor told us that 'I'm much more interested in what is the nature of the IP. Is it knowhow, protected, proprietary, can other people copy it, and how long does it take for them to catch up if they want to compete?'

Where there are litigation issues surrounding patenting activity, again the investment is likely to be lower, if it takes place at all: for example, 'if there are litigation costs we wouldn't want to get involved'. Again this is unsurprising, as an investor will be unlikely to commit as much as he might otherwise to an investment where a patent is under some dispute. As one investor explained in more detail:

'As far as patents go, they're very difficult to value and very difficult to know how useful they are to the company. There was litigation between us and [another company]. They had to pay [us] \$1.2bn. A series of patents to them would have been worth $\$ 1.2 \mathrm{bn}$. A patent is a sword, not a shield; it's to defend yourself with, to stab a company with it if you need to. It is a very offensive tool or weapon. It is a defence mechanism, but you're not shielding yourself behind it, because in its inert state it does nothing for you; it's only there if someone tries to do what you have a right to do, because you have developed it.'

The majority of our respondents stated that there was no link between patents and the level of investment, saying, for example, 'it's important to have patents, but it doesn't play that much into the investment opportunity; it doesn't correlate that much with the risk of the business'; 'patents and profitability are not linked'; and 'there will be a lot more than just the patent that makes the value'. One investor explained his thoughts as follows:

'I think there can be businesses into which you put a large amount of money, which have small amounts of patents and can be very successful. To some extent, those which have a large number of patents are R\&D heavy and you may struggle to make a good return. Actually, when the patent numbers go right up you start to wonder whether the business is too capital intensive. So there's a 
positive correlation for a small number of patents, but once you've passed a threshold it becomes a negative correlation to performance'.

Even fewer perceived a similar link between the percentage equity stake requested and patents applied for $(17 \%)$ or patents owned $(11 \%)$, stating, for example, 'at the end of the day we invest on the business proposition as a whole, and the value of patents are only a part of the equation'; 'there are different dynamics involved when it comes to ... how much equity you take in the business'; and 'if we qualified it as commercially viable we request a lower equity stake'. One investor gave the following example from practice:

'The amount invested is made on what commercial return we can make. So, to give you an example, we are shareholders in a company ... which has a fantastic family of patents. It comes out of [Oxbridge] University, it has patents around the best antennas in the world for mobile phones and tablets; however the way the industry works is price-related. Price is incredibly important and no one is prepared to pay more than $25-30 \%$ gross margin because we have better antennas and we have patents, and so to equate patents and profitability is wrong. Sony Ericsson breached the patent and the company sued them; the case was won and they settled by effectively buying a licence for under a million pounds. Not only do you need to have the patent, but you need to be able to enforce the patent and, for little companies, this can be difficult because they're big guys, and there were lawyer fees of half a million pounds. To link the two, even though the company has a fantastic portfolio of patents and manages them very well: one, it's an OK investment, though not a hugely successful investment; and two, we had to fight back to protect our patents.'

Investors were then asked to assess the level of importance of a number of features of patent ownership, prior to making the decision whether or not to invest [cf. Appendix, Respondent Sheet 1]. These responses were measured on a Likert scale from 1 (how importance) to 5 (high importance). The most important attribute, in this case, was seen to be the importance of patents to the specific industry in which the potential business was operating (mean response $=4.24$ ) e.g. "where a patent is important to the industry, then we are sure to get lots of them'. One investor explained further: 'From a practical good use of my investment capital I would want the entrepreneur to prove to me that building a family of patents is valuable ... because I'm a software investor, and very rarely can software patents be circumvented.'

The residual life of the patent was next most important (4.19), followed by the existence of substitute or alternative products (4.10) and any on-going patent litigation issues (4.05). As one investor explained, 'it can depend very much on the sector so, if it's biotech, it [residual life] has a direct impact'. To attenuate the 
threats of substitutes, they might perform 'patent landscaping [to find out] who are the other people patenting in that area, are there risks of infringements, and so on'. Patent scope, which measures the different classifications of a patent, was also important (3.71), as was having the involvement of the inventor in the business (3.62). The patent status (applied for, pending, granted etc) (3.52) and family size (geographical coverage) (3.43) were of lesser importance to the investor's decision: e.g. patent status 'doesn't matter if we believe we can commercialise it'; and 'it's most important to have [protection in] key jurisdictions'. And of least importance, on average, were said to be measures of citations and/or simple patent count. One investor gave the following example, from his own experience of investing:

'In healthcare, life sciences patents are important. It's very difficult to imagine growing a business if you can't provide barriers to entry for others. This is an expensive business. Discovering and developing drugs is very expensive, so you have barriers. I would say that the scope of the patents is also pretty important for us. For instance, if you have a chemical that you file on that structure but not on any related structures, they'll find ways round it, modify it slightly, so you need to have quite wide scope. If you're developing a drug for multiple sclerosis, you want to cover for many other related diseases as well.'

\section{Conclusion}

We began this research with the aim of trying to understand whether or not the existence of patenting drives the venture capital investor to support a high-tech company (e.g. Odasso and Ughetto, 2011) and, if so, how that investment value is derived (cf. Sherry \& Teece, 2004). Previous work has found contradictory evidence surrounding this issue. One of our respondents from the earlier fieldwork, a European Patent Attorney, gave us his thoughts as to why investors claim that there is no link between the amount invested and the number of patents a firm holds:

'[It is] because the investor is very cautious, and [because of] the subjectivity involved. He is likely to be inclined to say that there is no relationship - despite studies having shown that such a relationship exists. They often state that their decision was based on the basis of the management, or the business strategy. Although valuation may be useful for the investors, often they are unwilling to obtain such information in view of the costs involved. However, very often they do try and seek some form of advice from patent lawyers and other experts in the field'.

The investor makes his money by being good at what he does; his due diligence and the ability to appraise potential investments at an early stage can be the difference between backing winners or losers. He 
plays a strategic game (cf. Holgersson, 2013), and will happily keep back information from the market, if he thinks that this will provide him with an advantage over potential rival investors. Therefore, to admit that patenting information may be useful, when this information, with a little bit of effort, is available to any investor, might be contrary to his natural tendencies.

What we have found, in our study above, is that there is evidence of a link between the existence of patenting and the level of investment made by the high-technology venture capital investor (Baum \& Silverman, 2004). There are certainly some among them who admit that patenting acts as a signal, either of innovation or potential value. Yet, when we ask explicitly whether patenting has a direct impact upon the investment they will make, they are reluctant to admit that it does.

The entrepreneur who starts up a high-technology company might wonder whether the act of seeking a patent is worthwhile, especially if the evidence of venture capitalists' use of such measures is equivocal. What we would say, from our analysis of empirical evidence of practice, is that, yes, it is worth seeking some form of protection via the patenting route. Of those investors we spoke to, many seemed to acknowledge that having some form of protection of intellectual property, through wider patent scope or patent families, was crucial in maintaining a leading position in the marketplace and for fending off potential competitors. And those investors who thought that patenting was important tended to also invest more into high-tech companies, even if they did not admit that there was an explicit link between the two. In this regard, the UK's government policy of providing tax breaks for patenting is a welcome step for high-tech firms.

We accept that our results are founded on a relatively small sample of observations. However, they do provide illuminating insight into current practice in venture capital investment in high-tech firms, in particular. We have presented descriptive statistics which help to provide an overview of the nature of this investment, which is known to play a key role in growth and innovation (cf. Bottazzi et al, 2008). We support this with insightful additional commentary from investors themselves into how and why they make investments, the like of which is currently lacking in existing literature. A useful next step would be to develop the database on investment and patenting, in order to perform analysis on a larger body of evidence. 
However, in the meantime, while acknowledging the limitations of our work, we suggest that it provides a unique insight into the impact of patenting on venture capital decision-making.

\section{References}

Ante, S. E. (2008). Creative capital : Georges Doriot and the birth of venture capital. Boston, Mass.: Harvard Business Press.

Armstrong, C., Davila, A., \& Foster, G. (2006). Venture-backed private equity valuation and financial statement information. Review of Accounting Studies, 11(1), 119-154.

Baum, J. A. C., \& Silverman, B. S. (2004). Picking winners or building them? Alliance, intellectual, and human capital as selection criteria in venture financing and performance of biotechnology startups. Journal of Business Venturing, 19(3), 411-436.

Benassi, M. \& Di Minin, A. (2009). Playing in between: patent brokers in markets for technology. $R \& D$ Management, 39(1), 68-86.

Bertoni, F., Croce, A., \& D'Adda, D. (2010). Venture capital investments and patenting activity of high-tech start-ups: a micro-econometric firm-level analysis. Venture Capital: An International Journal of Entrepreneurial Finance, 12(4), 307 - 326.

Bottazzi, L, M. Da Rin \& T. Hellmann. (2008). Who are the active investors? Evidence from venture capital. Journal of Financial Economics, 89, 488-512.

Breitzman, A., Thomas, P. \& Cheney, M. (2002). Technological powerhouse or diluted competence: techniques for assessing mergers via patent analysis. $R \& D$ Management, 32(1), 1-10.

British Venture Capital Associaton. (2011). BVCA Private Equity and Venture Capital Report on Invesmtent Activity 2010 Retrieved 1st December, 2011, from http://admin.bvca.co.uk/library/documents/RIA_2010.pdf

Burgess, R. G. (1984). In the field : an introduction to field research. London: Allen \& Unwin.

Carpenter, R.E., and B.C. Petersen. (2002). Capital market imperfections, high-tech investment, and new equity financing. The Economic Journal 112(477), F54-F72.

Cockburn, I. M., \& MacGarvie, M. J. (2009). Patents, Thickets and the Financing of Early Stage Firms: Evidence from the Software Industry. Journal of Economics \& Management Strategy, 18(3), 729-773.

Conti, A., Thursby, M. C., \& Rothaermel, F. (2011). Show Me the Right Stuff: Signals for High Tech Startups: National Bureau of Economic Research.

Dushnitsky, G., \& Lenox, M. J. (2005). When do incumbents learn from entrepreneurial ventures?: Corporate venture capital and investing firm innovation rates. Research Policy, 34(5), 615-639.

Engel, D., \& Keilbach, M. (2007). Firm-level implications of early stage venture capital investment--An empirical investigation. Journal of Empirical Finance, 14(2), 150-167.

Ernst, H. \& Witt, P. (2005). Corporate venture capital as a strategy for external innovation: an exploratory empirical study. R\&D Management, 35(3), 233-42.

Ernst, H. (2003). Patent information for strategic technology management. World Patent Information 25(3), 233-242.

Gompers, P., \& Lerner, J. (2001). The venture capital revolution. The Journal of Economic Perspectives, 15(2), 145-168.

Graham, S., Merges, R. P., Samuelson, P., \& Sichelman, T. (2010). High technology entrepreneurs and the patent system: Results of the 2008 Berkeley patent survey. Berkeley Technology Law Journal, 24(4), $1255-1328$.

Granstrand, O. (1998). Towards a theory of the technology-based firm. Research policy, 27, 465-89.

Granstrand, O. (1999). The economics and management of intellectual property: Towards intellectual capitalism. Cheltenham, UK: Edward Elgar. 
Granstrand, O. (Ed.). (2003). Economics, law and intellectual property: seeking strategies for research and teaching in a developing field. Springer.

Griliches, Z. (1998). Patent statistics as economic indicators: a survey. Chapter 13 in R\&D Productivity: The Econometric Evidence; University of Chicago Press; Chicago, pp.287-343.

Guest, G., Bunce, A., \& Johnson, L. (2006). How many interviews are enough? An experiment with data saturation and variability. Field Methods, 18(1), 59-82.

Haeussler, C., Harhoff, D., \& Muller, E. (2012). To Be Financed or Not... - The Role of Patents for Venture Capital Financing. SSRN eLibrary.

Hall, B.H., Jaffe, A. \& Trajtenberg. M. (2000). Market Value and Patent Citations: A First Look, Economics Working Papers E00-277, University of California at Berkeley.

Hall, B.H., Jaffe, A. \& Trajtenberg. M. (2005). Market Value and Patent Citations. RAND Journal of Economics 36(1), 16-38.

Hand, J. R. M. (2005). What drives the top line? Nonfinancial determinants of sales revenue in private venture-backed firms: Working paper: University of North Carolina-Chapel Hill.

Harhoff, D., Scherer, F. M., \& Vopel, K. (2003). Exploring the tail of patented invention value distributions. In O. Granstrand (Ed.) Economics, law and intellectual property: seeking strategies for research and teaching in a developing field. Springer, (pp. 279-309).

Hayton, J.J. (2005). Competing in the new economy: the effect of intellectual capital on corporate entrepreneurship in high-technology new ventures. R\&D Management, 35(2), 137-55.

Hellman, T., \& Puri, M. (2000). The interaction between product market and financing strategy: The role of venture capital. Review of Financial studies, 13(4), 959-984.

Hirschey, M., Richardson, V., \& Scholz, S. (2001). Value relevance of nonfinancial information: The case of patent data. Review of Quantitative Finance and Accounting, 17(3), 223-235.

HM Treasury. (2013). HMRC Corporate Intangibles Research \& Development Manual, CIRD 200000. HM Treasury London.

http://www.hmrc.gov.uk/manuals/cirdmanual/CIRD200110.htm, Accessed 14 May 2013

Holgersson, M. (2013). Patent management in entrepreneurial SMEs: a literature review and an empirical study of innovation appropriation, patent propensity, and motives. $R \& D$ Management 43(1), 21-36.

Hsu, D. H., \& Ziedonis, R. H. (2007), June 18-20). Patents as quality signals for entrepreneurial ventures. Paper presented at the DRUID Summer Conference, Copenhagen.

Intellectual Property Office. (2011) Patents Act (1977) (as amended), Patent Office, Newport.

Jackson, B. A. (2003). Innovation and intellectual property: the case of genomic patenting. Journal of Policy Analysis and Management, 22(1), 5-25.

Jeng, L.A., and P.C. Wells. (2000). The determinants of venture capital funding: evidence across countries. Journal of Corporate Finance 6(3), 241-289.

Klein, S. (2013). We are the $8 \%$ - why tech companies matter to the UK economy. The Guardian, 1 March. http://www.guardian.co.uk. Accessed 4 June 2013.

Knockaert, M., Clarysse, B. \& Wright, M. (2010). The extent and nature of hereogeneity of venture capital selection behaviour in new technology-based firms. $R \& D$ Management 40(4), 357-71.

Kortum, S., \& Lerner, J. (2000). Assessing the contribution of venture capital to innovation. RAND Journal of Economics, 31(4), 674-692.

Lanjouw, J.O., Pakes, A., \& Putman, J. (1998). How to count patents and value intellectual property: the uses of patent renewal and application data. The Journal of Industrial Economics XLVI(4), 0022-1821.

Lemley, M. A. (2000). Reconceiving patents in the age of venture capital. Journal of Small and Emerging Business Law, 4, 137.

Lerner, J. (2002). Boom and bust in the venture capital industry and the impact on innovation. Economic Review-Federal Reserve Bank of Atlanta, 87(4), 25-40.

Littler, D.A. \& Pearson, A.W. (1979). Rewarding the employee inventor and the Patents Act (1977). $R \& D$ Management, 10(1), 29.

Long, C. (2002). Patent signals. The University of Chicago Law Review, 69, 625-679. 
Lynskey, M. J. (2004). Determinants of innovative activity in Japanese technology-based start-up firms. International Small Business Journal, 22(2), 159.

Mann, R. J., \& Sager, T. W. (2007). Patents, venture capital, and software start-ups. Research Policy, 36(2), 193-208.

Mason, C. (1999). Editorial. Venture Capital: Rationale, aims and scope. Venture Capital, 1(1), 1-46.

Mason, C., \& Harrison, R. T. (2004). Improving access to early stage venture capital in regional economies: a new approach to investment readiness. Local Economy, 19(2), 159-173.

Merges, R.P. \& Nelson,. R.R. (1990). On the complex economics of patent scope. Columbia Law Review 90(4), 839-916.

Morgan, G., \& Smircich, L. (1980). The case for qualitative research. Academy of management review, 491500.

Mulder, K.F. \& Vergragt, P.J. (1991). How a patent conflict affects industrial R\&D management. $R \& D$ Management, 21(1), 3-10.

Munari, F., \& Toschi, L. (2014). Do patents affect VC financing? Empirical evidence from the nanotechnology sector. International Entrepreneurship and Management Journal, 1-22.

Nadeau, P. (2010). Venture capital investment selection: do patents attract investors? Strategic Change, 19, 325-342.

Narin, F. (1994). Patent bibliometrics. Scientometrics, 30(1), 147-55.

Odasso, M.C. \& Ughetto, E. (2011). Patent-backed securities in pharmaceuticals: what determines success or failure? R\&D Management, 41(3), 219-39.

Qu, S.Q. and Dumay, J. (2011). 'The qualitative research interview', Qualitative Research in Accounting and Management 8(3), 238-64.

Sakata, J., Suzuki, K. \& Hosoya, J. (2009). The analysis of research and development efficiency in Japanese companies in the field of fuel cells using patent data. $R \& D$ Management, 39(3), 291-304.

Scherer, F. M. (1999). New perspectives on economic growth and technological innovation. Brookings Institution Press.

Schertler, A. (2007). Knowledge capital and venture capital investments: new evidence from European panel data. German Economic Review, 8(1), 64-88.

Seppä, T.J. \& Laamanen, T. (2001). Valuation of venture capital investments: empirical evidence. $R \& D$ Management, 31(2), 215-30.

Sherry, E.F. \& D.J. Teece. (2004). Royalties, evolving patent rights, and the value of innovation. Research Policy 33, 179-91.

Smith, J. A., \& Cordina, R. (2014). The role of accounting in high-technology investments. The British Accounting Review. http://dx.doi.org/10.1016/j.bar.2014.03.002.

Stevens, H.A.R. (1972). Criteria for selection of venture capital projects: reasons behind successes and failures in the past. $R \& D$ Management, 3(1), 41-5.

Ueda, M., \& Hirukawa, M. (2008). Venture Capital and Industrial 'Innovation'. SSRN eLibrary.

Wiltbank, R. E. (2009). Siding with the Angels: Business Angel investing-promising outcomes and effective strategies. London: British Business Angels Association. 


\section{APPENDIX \\ Excerpt from Administered Questionnaire}

1. During the screening process, various aspects relating to intangibles will be considered. Indicate at which stage you would consider the following:

(Tick all that apply)

In the qualification stage proposals are screened and those which do not meet the investment criteria established by the venture capital investor are rejected without further consideration. In the initial enquires and negotiation stage, additional information is provided, and the business plane with discussed. Outline terms are negotiated at this stage, and valuation of the business is made by the venture capital firm. In the due diligence stage a detailed assessment of the financial and technical feasibility of the investment is made.

We define structural capital as the knowledge which remains within the firm at the end of the day (e.g. databases, organisational culture etc.) Human capital refers to the knowledge the employees retain even when they leave the firm. Relational capital relates to the resources which are externally linked to the company, its customers and its suppliers, and R\&D partners.

\begin{tabular}{|l|l|l|l|}
\hline & Qualification & $\begin{array}{c}\text { Initial enquiries \& } \\
\text { negotiation }\end{array}$ & Due Diligence \\
\hline $\begin{array}{l}\text { Structural Capital: } \\
\text { Innovation }\end{array}$ & & & \\
\hline $\begin{array}{l}\text { Structural Capital: } \\
\text { Business model }\end{array}$ & & & \\
\hline $\begin{array}{l}\text { Structural Capital: } \\
\text { Intellectual Property }\end{array}$ & & & \\
\hline $\begin{array}{l}\text { Relational Capital: } \\
\text { Reputation amongst } \\
\text { stakeholders }\end{array}$ & & & \\
\hline $\begin{array}{l}\text { Relational Capital: } \\
\text { Customer base and market } \\
\text { share }\end{array}$ & & & \\
\hline Relational Capital: Investors & & & \\
\hline $\begin{array}{l}\text { Human Capital: Management } \\
\text { team }\end{array}$ & & & \\
\hline $\begin{array}{l}\text { Human Capital: } \\
\text { Remuneration scheme }\end{array}$ & & & \\
\hline
\end{tabular}

Patents

2. Do you consider patents to be a sign of:

(a) A profitable investment opportunity

(b) Innovative potential

(c) Entrepreneurial ability and experience

(d) Less effort required by the venture capitalist

$\begin{array}{ll}\text { Yes } \square & \text { No } \square \\ \text { Yes } \square & \text { No } \square \\ \text { Yes } \square & \text { No } \\ \text { Yes } \square & \text { No }\end{array}$

2.1 Briefly explain the reasons for your answer

3. Do you perceive there to be a link between the amount invested and whether or not the company has applied for patents? Yes $\square \quad$ No $\square$

3.1 Briefly explain the reasons for your answer, explaining how this link (if any) is reflected in the investment decision?

4. Is there a link between the amount invested and whether or not the company owns patents?

Yes $\square \quad$ No $\square$

4.1 Briefly explain the reasons for your answer, explaining how this link (if any) is reflected in the investment decision?

5. Do you perceive there to be a link between the $\%$ of equity requested from entrepreneur and whether or not the firm has applied for patents?

Yes $\square \quad$ No $\square$ 
5.1 Briefly explain the reasons for your answer, explaining how this link (if any) is reflected in the investment decisions?

6. Is there a link between the \% of equity requested from entrepreneur and whether or not the firm owns patents?

Yes $\square \quad$ No

6.1 Briefly explain the reasons for your answer, explaining how this link (if any) is reflected in the investment decision?

7. In assessing patent ownership, prior to an investing, please rank the importance of the following patent related attributes Refer to respondent sheet 1

8. In your experience how likely is a firm to increase the number of patents after the initial investment?

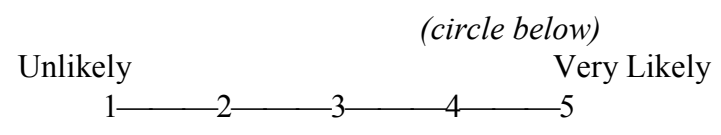

8.1 Please explain the reason for the answer given in question

9. Prior to investing are you interested in the financial valuation attributable to patents owned by the entrepreneur Yes $\square$ (proceed to question 10) No $\square$

9.1 Briefly explain the reasons for your answer

10. Do you engage experts/external consultants such as patent lawyers or science experts in order to provide advice on the patents?

Yes $\square$ (proceed to question 10.1) No $\square$ (proceed to question 10.3)

10.1. Indicate on what aspects of patenting advice sought

10.2. Do you request a valuation of the patent from the expert prior to investing?

Yes $\square$ No $\square$ (go to question 10.3)

10.3. Explain why experts are not engaged to evaluate patents?

11. Are you willing to have this valuation shown on the face of financial statements after investing

Yes $\square$ (go to question 12) No $\square$ (go to question 11.1)

11.1 Please explain why? (tick all that apply)

(a) It is still not accurate enough

(b) Competition related arguments

(c) Tax implications

(d) Other (please explain)

12. Do you request a valuation of the patent during the course of the investment?

Yes $\square \quad$ No $\square$

12.1 Please explain the reason for requesting/not requesting same

13. Do you engage other experts to provide assistance relating to other intangibles e.g. psychologists to assess human capital? Yes $\square \quad$ No $\square$

13.1 If yes please explain which experts, and for what

14. Do entrepreneurs supply valuation of patents from third parties (prepared prior to approaching the investor) - tick one only

Always

Most of the times $\square$

Sometimes

Rarely

Never 


\section{Respondent Sheet 1}

25. In assessing patent ownership, prior to making an investment, how do you rate the importance of the following patent related attributes?

(a) Residual life of patent

(b) Number of backward citations (reference to other patents)

(c) Number of forward citations

(a) Family size

(Number of jurisdictions in which protection is sought)

(b) Simple patent count

(c) Patent status (applied for, granted etc.)

(d) Patent litigation issues

(e) Inventor involvement

(f) Patent scope (as measured by the number of different classifications)

(g) Existence of substitutes to the patented technology

(h) Importance of patents within the specific industry
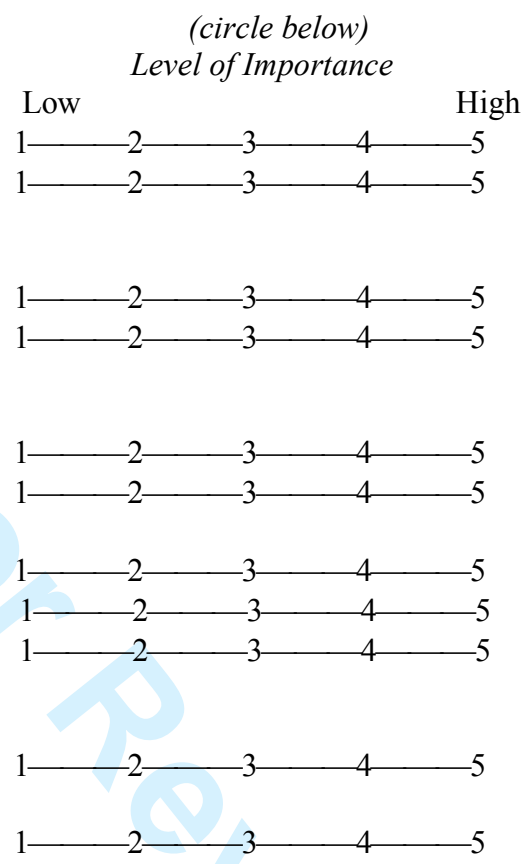

Thank you.

Now please hand this sheet back to the interviewer 


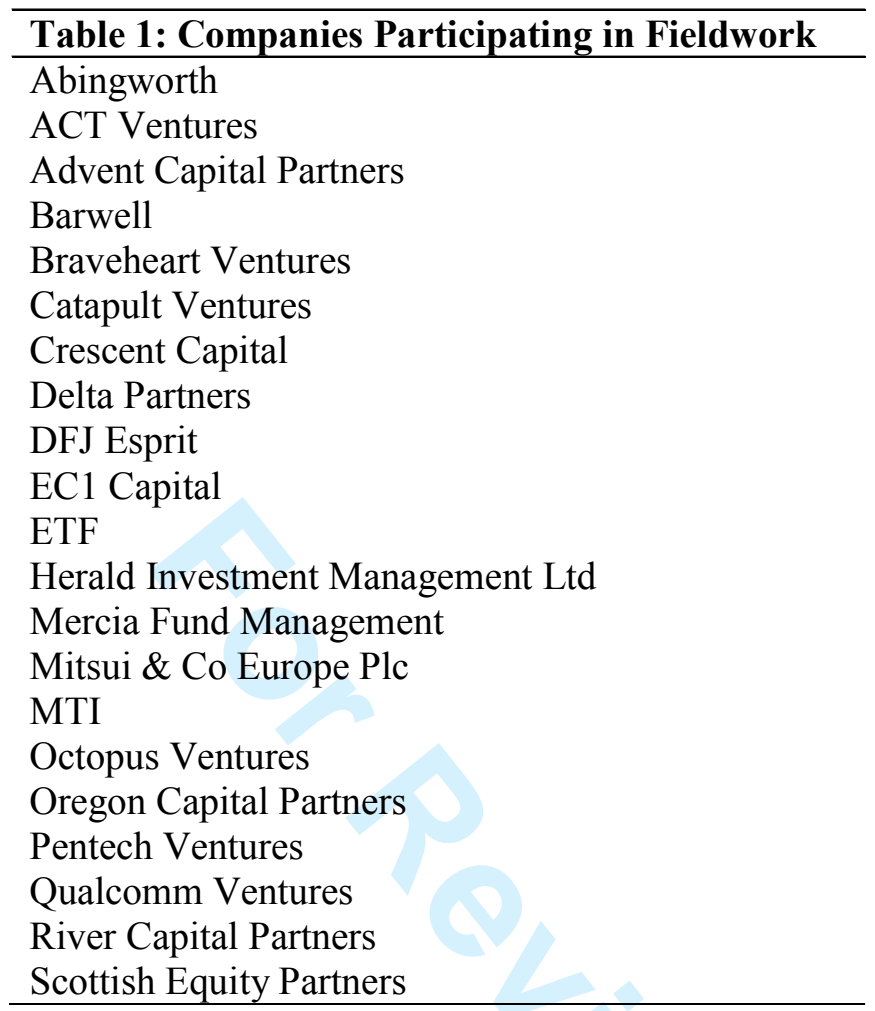


Table 2: Descriptive Statistics for the Sample

\begin{tabular}{|c|c|c|c|c|c|}
\hline & $\mathbf{N}$ & Minimum & Maximum & Mean & Std. Deviation \\
\hline \multicolumn{6}{|l|}{ Stage of Investment } \\
\hline Other early stage & 21 & 0 & 1 & .76 & .44 \\
\hline Seed & 21 & 0 & 1 & .71 & .46 \\
\hline Startup & 21 & 0 & 1 & .71 & .46 \\
\hline Expansion & 21 & 0 & 1 & .67 & .48 \\
\hline Management buy-out & 21 & 0 & 1 & .05 & .22 \\
\hline Management buy-in & 21 & 0 & 1 & .05 & .22 \\
\hline Institutional buy-out & 21 & 0 & 1 & .05 & .22 \\
\hline Secondary purchases & 21 & 0 & 1 & .05 & .22 \\
\hline Refinancing bank debt & 21 & 0 & 1 & .05 & .22 \\
\hline Bridge financing & 21 & 0 & 1 & .05 & .22 \\
\hline \multicolumn{6}{|l|}{ Preferred Sector } \\
\hline Medical & 21 & 0 & 1 & .81 & .40 \\
\hline Internet & 21 & 0 & 1 & .76 & .44 \\
\hline Mobile telecommunications & 21 & 0 & 1 & .62 & .50 \\
\hline Software & 21 & 0 & 1 & .62 & .50 \\
\hline Medical Equipment & 21 & 0 & 1 & .57 & .51 \\
\hline Healthcare & 21 & 0 & 1 & .57 & .51 \\
\hline $\begin{array}{l}\text { Fixed line } \\
\text { telecommunications }\end{array}$ & 21 & 0 & 1 & .48 & .51 \\
\hline Computer hardware & 21 & 0 & 1 & .48 & .51 \\
\hline Semiconductors & 20 & 0 & 1 & .45 & .51 \\
\hline Biotechnology & 21 & 0 & 1 & .43 & .51 \\
\hline Pharmaceuticals & 21 & 0 & 1 & .24 & .44 \\
\hline \multicolumn{6}{|l|}{ Preferred Region } \\
\hline Europe & 21 & 0 & 1 & .48 & .51 \\
\hline National & 21 & 0 & 1 & .29 & .46 \\
\hline Worldwide & 21 & 0 & 1 & .14 & .36 \\
\hline Regional & 21 & 0 & 1 & .10 & .30 \\
\hline Local & 21 & 0 & 0 & .00 & .00 \\
\hline \multicolumn{6}{|l|}{ Size of Investment } \\
\hline Highest Investment (£m) & 21 & .15 & 20.00 & 5.10 & 5.77 \\
\hline Lowest Investment (£m) & 20 & .01 & 15.00 & 2.13 & 4.55 \\
\hline Average Investment (£m) & 11 & .13 & 5.00 & 2.03 & 1.54 \\
\hline Highest Equity Stake (\%) & 11 & 5 & 80 & 33.18 & 19.14 \\
\hline Lowest Equity Stake (\%) & 11 & 5 & 50 & 15.00 & 12.25 \\
\hline Average Equity Stake (\%) & 5 & 20 & 30 & 27.00 & 4.47 \\
\hline
\end{tabular}




\section{Table 3: Views on Patenting}

N Min. Max. Mean Std. Dev.

${ }^{I}$ Patenting is a signal of:

Innovative potential

Entrepreneurial ability and experience

A profitable investment opportunity

Less effort required by venture capitalist

$\begin{array}{lllll}18 & 0 & 1 & .83 & .39\end{array}$

$\begin{array}{lllll}18 & 0 & 1 & .28 & .46\end{array}$

$\begin{array}{lllll}19 & 0 & 1 & .21 & .42\end{array}$

${ }^{I}$ There is a link between:

Amount invested and patents applied for

Amount invested and patents owned

Equity required and patents applied for

Equity required and patents granted

20

0

.10

.31

${ }^{2}$ Importance of patent attributes prior to investment:
Importance of patents to specific industry
Residual life of patent
Existence of substitutes
Patent litigation issues
Patent scope
Inventor involvement
Patent status
Family size
Number of forward citations
Simple patent count
Number of backward citations

$\begin{array}{lllll}17 & 0 & 1 & .24 & 44\end{array}$

$\begin{array}{lllll}17 & 0 & 1 & .24 & .44\end{array}$

$\begin{array}{lllll}18 & 0 & 1 & .17 & .39\end{array}$

$\begin{array}{lllll}18 & 0 & 1 & .11 & .32\end{array}$

Notes: ${ }^{1}$ respondents answered $=0$ 'no', =1 'yes'; 'respondents answered =0 'negligible' to $=5$ 'high importance' 